\title{
DIFFERENCES OF PROPORTION OF DISTRACTORS NUMBERS OF ECONOMIC QUESTION ITEM FOR SENIOR HIGH SCHOOL CLASS XI IN BEKASI CITY
}

\author{
Roro Ernawati Raden \\ roro.erns@gmail.com \\ Universitas Negeri Jakarta \\ Supriyati, Yetti \\ y_supriyati@yahoo.com \\ Universitas Negeri Jakarta \\ Dudung, Agus \\ agusdudung65@gmail.com \\ Universitas Negeri Jakarta
}

\begin{abstract}
ABSTRAK
The purpose of this research to measure the differences of distractors of proportion number in economic question item. This research was an experiment in a senior high school in Bekasi. The sample of the research was obtained technically cluster random sampling. Data was analyzed by one way analyzed of variance (ANOVA) $3 \times 1$ treatment by level design. The results of this research is rejected hypothesis based on ANOVA number significant (0.127) higher than degree freedom (0.005). The conclution is distractors proportion two, distractors proportion three, and distractors proportion four have same proportion that's no different absolutely. The results of the reseach recommended that the teacher used distractors two, distractors three, and distractors four in the learn process.and paid attention to teacher competency for the readiness of student.
\end{abstract}

Keywords: distractors proportion number, multiple choices, distractors items, economic items, economic education and teaching of economics, design of experiments, data collection, sampling methods, eduacation

\section{INTRODUCTION}

Item difficulty is the proportion of examinees answer the question correctly, with lower values reflect more difficult questions. All distractors with a choice frequency of $<5 \%$ were identified. We further computed the discriminating power of all distractors and identified distractors with positive discriminating power (nonfunctioning distractors)(Marie, 2009).

The hesitation of students in determine the correct answer is affected by difficulty items level that students choose the distractors. The evaluation test is multiple choice because easy and fast for the score, objective, easy analysis, involve the comphrehensive materials in test, able to measure the low competencies until high competencies (Musmuliadi, 2009).

Of further concern is the high proportion of items that did not have any functioning distractors (12.3\%). These items would inevitably have high item difficulty statistics (>.90) with almost all students getting the items correct. When absolute pass scores are used and set at a fixed percentage (i.e., 50\%), as they are in the institution where these tests were administered, such a high proportion of easy items likely results in many borderline candidates passing who should not(Marie, 2009).

Item analysis in answer proportion estimation to assess the difficulty index and discrimination of questions quality. The difference of answer proportion show 
number the correct answers of all answers. Difficulty index will be declared in various kinds. One of kinds is correct answer (Naga, 2012).

Distractors play a vital role for the process of multiplechoice testing, in that good quality distractors ensure that the outcome of the tests provides more credible and objective picture of the knowledge of the testees involved. On the other hand, poor distractors would not contribute much to the accuracy of the assessment as obvious or too easy distractors will pose no challenge to the students and as a result, will not be able to distinguish high performing from low performing learners(Mkrtchyan, 2011).

The MC items on 13 of the 16 tests had four options, and on the remaining tests, they had five. Therefore, there were 3819 distractors in the data set, and many were flawed. More than one-third (37.3\%) of the distractors were flawed because they were chosen by less than 5\% of examinees(Kurzawa, 2011).

Analyzing the distractors (incorrect alternatives) is done to determine their relative usefulness in each item. Items need to be modified if students consistently fail to select certain distractors. Such alternatives are probably implausible and therefore of little use as decoys(Sanju, 2014).

Three-option items have also been recommended in the literature because of their ease of preparation as these require fewer distractors, take up less space, require less reading time, and decrease time for item development and administration(Rashmi, 2008).

Based on options three and penalty score technic research have high of realibility. Options three more efficient by processing time aspect and make of distractor aspect. While of penalty score technic, students more scared when the answer is wrong and get punishment so the score technic have a high of realibility(Bhakti, 2015).

Another part of item question analysis is measure about number of correct answer items and wrong answer items that evaluate for arrangement the continuous items questions when we are found one of items can not reflection the students competency.

Based on the earlier research at SMAN 1 Bekasi, the result of proportion score of distractors four is $9,35 \%$, Standard Deviation (SD) is 2,89 and avarege score is 62,33 that moderate category of difficulty level. The lowest score is 20 and highest score is 93,33 of 15 questions. The early research at SMA PGRI 1 Bekasi show on two distractors is $8.90 \%$ of proportion, deviation standard is 1.68 and avarege score 59,33\% that lower category. The lowest score is 33 and highest score is 80 of 15 questions. Differences proportion result both of distractors two and distractors four are proportion score of distractors four higher than proportion score of distractors two.

As for characteristic of economic subjects is economic science start from a fact or real economic indication, economic science develop the theories to description of a fact rationally. and generally in analysis for economic science is method of problem solve(Norani, 2012).

Based on the descriptions above then need do a research about differences of distractors numbers on economic items that know the differences of proportion of each items on multiple choices questions. 


\section{METHOD}

The research is quantitative research use experiment method of treatment by level $3 \times 1$ design on table 3.1. Compare the proportion of distractors numbers of each items.

Consideration of choose the design is capability to measure the difference proportion of distractors numbers on economic items questions. Sample in this research use cluster random samplingtechnic. There are 600 students for all distractors sample and 200 students of each distractors sample.

Table-1. Research Design

\begin{tabular}{l|l|l}
\hline Distractor & \multicolumn{2}{l}{} \\
\hline Two & Three & Four \\
\hline$X_{1}$ & $X_{2}$ & $X_{3}$ \\
\hline
\end{tabular}

Source: Data of research design treatment $3 \times 1$ years 2017

Population target are students grade 11 in senior high school major social science at Bekasi city in study year 2017/2018. Sample are 40 distractors items of 200 students of each distractors. Then, count the proportion score of 600 students base on the numbers of distractors. 40 items as respondents score will analysis by statistic test and hypotesis test.

Cluster Random Sampling on Bachtiar research are categorize age and gender, not use the social level or area criteria. The reason of Categorize are age and gender that people of $30-70$ ages above interest to the Khazanah program(Bachtiar, 2015).

Three kinds of data collected are below: (1) data of differences proportion of distractors numbers four in economic items questions by result of distractor four economic items test, (2) data of differences proportion of distractors numbers three in economic items questions by result of distractor three economic items test, (3) data of differences proportion of distractors numbers two in economic items questions by result of distractor two economic items test.

Data collected by develop an economic questions instrument in multiple choices. Five matters important that are (1) arrange the construct definition, (2) arrange the operational definition, (3) arrange the indicator of test base on each characteristic test, (4) arrange the items test, and (5) validity test of 20 experts, validity of economic experts, validity of empiric by point biserial correlation and realibility by KR-20.

Data are process with descriptive statistic and statistic requirements test that are normalitas test; homogeneity test, statistic test, hypothesis tes. Normality test by Liliefors test on $\alpha=0,05$. Homogeneity test by Bartlett test on $\alpha=0,05, \mathrm{db}=\mathrm{k}$ - 1(Sudjana, 2009). Hypothesis test by varians analysis (ANAVA) one way to know the significant of differences distractors of proportion numbers in economic items by dichotomous test of students grade 11 social science. 


\section{RESULT}

Result the differences of distractors of proportion numbers economic items by 40 items test of 200 students of each distractors that show in table .

Table-2. Resume Score of Distractors Proportion Numbers Economic Items in All Experiment Groups Base on Descriptive Statistic Scale

\begin{tabular}{l|l|l|l}
\hline \multirow{2}{*}{ Note } & Distractor & \multicolumn{3}{|l}{} \\
\cline { 2 - 4 } & Distractor 2 $(\mathbf{X 1})$ & Distractor 3 $(\mathbf{X 2})$ & $\begin{array}{l}\text { Distractor } \\
(\mathbf{X 3})\end{array}$ \\
\hline $\mathrm{N}$ & 40 & 40 & 40 \\
\hline Mean & 50,162 & 38,8375 & 48.075 \\
\hline Std.Dev & 28,881 & 23,5536 & 27,5345 \\
\hline Minimum & 4 & 6 & 2 \\
\hline Maximum & 87 & 91 & 97 \\
\hline
\end{tabular}

Source: : Data of descriptive statistic scale years 2017

Normality Test

Normality test of distractors two of proportion data is $\mid \mathrm{S}(\mathrm{zi})$ - F(zi)| 0,12731 as high score. Lo $=0.12731$ and Ltable 0.1401. Lo < Ltable then Ho is accepted. The conclusion is data from normal distribution population.

Normality test of distractors three proportion data is $|\mathrm{S}(\mathrm{zi})-\mathrm{F}(\mathrm{zi})| 0,12947$ as high score. Lo $=0,12947$ and Ltable 0.1401. Lo < Ltable then Ho is accept. The conclusion is data from normal distribution population.

Normality test of distractors three proportion data is $|\mathrm{S}(\mathrm{zi})-\mathrm{F}(\mathrm{zi})| 0,12950$ as high score. Lo $=0.12950$ and Ltable 0.1401. Lo < Ltable then Ho is accept. The conclusion is data from normal distribution population.

\section{Homogenity Test}

Table-3. Homogenity Test Support

\begin{tabular}{l|l|l|l|l|l}
\hline $\begin{array}{l}\text { Sample } \\
\text { Group }\end{array}$ & $\mathbf{D k}$ & $\mathbf{S i}^{2}$ & $\mathbf{L o g} \mathbf{S i}^{2}$ & $\mathbf{d k .} \mathbf{S i}^{2}$ & dk.Log $\mathbf{S i}^{2}$ \\
\hline $\mathbf{X 1}$ & 39 & 834.1 & 2.92 & $\begin{array}{l}32529.6 \\
9\end{array}$ & 113.9 \\
\hline $\mathbf{X 2}$ & 39 & 554.2 & 2.74 & $\begin{array}{l}21613.9 \\
4\end{array}$ & 107.0 \\
\hline $\mathbf{X 3}$ & 39 & 758.1 & 2.88 & $\begin{array}{l}29567.7 \\
8\end{array}$ & 112.3 \\
\hline$\Sigma$ & 117 & 2146.4 & & $\begin{array}{l}83711.4 \\
1\end{array}$ & 333.2 \\
\hline
\end{tabular}

Source:Data of homogeneity test analysis years 2017

$\mathrm{S}^{2}$ is 117 , logarithm price of varian combined and price a Bartlet (B) is 333,9881 , then Chi Square score (Xo) is 1,72 . Test criteria is $X_{\text {count }}<X_{\text {table }}$ then $H_{\text {count }}$ is accept. $X_{\text {count }}=1,72$ and $X_{\text {table }}=5,99$. The conclusion is three of groups have homogeneous varians.

\section{Hypothesis Test}


The hypothesis test by varians analysis (ANOVA) one way to know differences of distractors numbers of proportion in economic items questions.

Table-4. Result Resume of ANOVA by F test about differences of distractors numbers proportion in economic items questions

\begin{tabular}{|c|c|c|c|c|c|c|}
\hline Source & $\begin{array}{l}\text { Square } \\
\text { Total }\end{array}$ & $\begin{array}{l}\text { Freedom } \\
\text { Degre } \\
\end{array}$ & Variety & Fo & $\mathbf{A}$ & Ftab \\
\hline $\begin{array}{l}\text { 1. } \mathrm{X} \text { between } \\
(\mathrm{X} 1, \mathrm{X} 2, \mathrm{X} 3)\end{array}$ & 2905.929 & 2 & 1452.965 & \multirow[t]{2}{*}{2.03} & \multirow[t]{2}{*}{0,05} & \multirow{2}{*}{3,07} \\
\hline 2. Galat & 83733.66 & 117 & 715.6723 & & & \\
\hline Total & 86639.59 & 119 & & & & \\
\hline
\end{tabular}

Source:Data of hypothesis test analysis years 2017

Discussion of the result are below.

\section{a Proportion of Distractor Two Higher Than Proportion of Distractor Three}

Result of hypothesis- 1 by treatment group $\mathrm{P}$ is $\mathrm{Fo}=2.03<\mathrm{Ftab}(\alpha=0,05)=3,07$ then Ho is accepted. Does not found the significant difference of distcrators two of proportion (X1) and distcrators three of proportion (X2). The research is originality by researcher and result of anava does not significant. Therefor, can not continuous test to know the higher both of group.

b Proportion of Distractor Three Higher Than Proportion of Distractor Four

Result of hypothesis- 2 by treatment group $\mathrm{P}$ is $\mathrm{Fo}=2.03<\mathrm{Ftab}(\alpha=0,05)=3,07$ then Ho is accepted. Does not found the significant difference of distcrators three of proportion (X2) and distcrators four of proportion (X3). The research is originality by researcher and result of anava does not significant. Therefor, can not continuous test to know the higher both of group.

\section{c Proportion of Distractor Two Higher Than Proportion of Distractor Four}

Result of hypothesis-3 by treatment group $\mathrm{P}$ is $\mathrm{Fo}=2.03<\mathrm{Ftab}(\alpha=0,05)=3,07$ then Ho is accepted. Does not found the significant difference of distcrators two of proportion (X1) and distcrators four of proportion (X3). The research is originality by researcher and result of anava does not significant. Therefor, can not continuous test to know the higher both of group.

Research is describe the data not support of hypothesis truth. The reasons are below:

First, total of correct answer that choose by responden will effect to $\pi$ or proportion score. According to Daali theory is more and more of correct answer then $\pi$ will higher more, and items is not difficult. The less of correct answer, then $\pi$ will be lower, and items is difficult more.

The strongest rationale for recommendation is 3-option format is that there is no significant change in the psychometric properties of this format when compared with the 4-option and 5-option formats(Rashmi, 2008).

Two, limitations of researcher in control the teacher competency that support of research in deliver the matters to students, then student readiness in finish the questions items is effected by matters control. Professional teacher is determinant factor in high quality education process(Soleh, 2009).

Students readiness in finish the distractors three have a tendency to guessing 
the correct answer, some answers of students is same that become limititation of researcher in control the teacher competency that support of research in deliver the matters to students. Teacher less attention in students understanding of matters. Teachers less attention of students understanding the matters, then students get difficult to choose the correct answer. Tend of students is guessing the answer randomly. As an opinion of Kuaseri is "distractors is incorrect answer, but posibble for someone get distract to choose its when does not understand of matters well"(Suprananto, 2012). Students does not understand the matters well, then easily to choose distractor, although distractor is lower level. Base on the data both of distractors two of proportion and distractors three of proportion has no significant different.

Find uncontrolled condition that teachers does not know of students understand the matters in test. Some students and teachers not familiar with HOTS test. Tend of the condition is effect by less effective communication between teachers and students, then students not ready do the test and choose the incorrect answer like guessing.

Martinis Yamin theory that professional teacher competent are:1) mastery of subject matters, 2) mastery and appreciation the foundation and educational concept and teacher, 3) mastery of educational process, teacher and student learn(Yamin, 2009).

The recommendation is teacher need increase of competence to teach and good communication with students, then increase of students knowledge. Furthermore, need to apply other form score technic beside of correct score technic, like penalty score and rewardscore.

As the researh by Yoga Budi Bhakti title of "Effect of Alternative Answer Number dan Score Technic to Test Reliability" that score of multiple choice test by penalty score technic and reward score technic. Penalty score technic of multiple choice that higher realibility than reward technic score. The cause is penalty score technic that's count total of wrong answer as punishment that reduction of score, with this score studnets are more careful do the test, then realibility of test will increase. Students does not understands of test don't want answer because worried the answer will be wrong and reduce the score(Bhakti, 2015).

Both of distractors two of proportion and distractors three of proportion has no significant different. The effect by teacher competence to students readiness and guessing the behavior of students. Expected the teachers have professionalism and increase of effective communication to students. Furthermore, relevance of score technic base on student's condition, like are penalty score and reward score, then students are more careful to choose the right answer and not easily to choose the available distractors. Then minimize of guessing behavior in test.

\section{CONCLUSION AND RECOMMENDATION}

Proportion of distractors two equals with proportion of distractors three, the result is anava test Fcount $(2,03)$ lower than Ftable $(3,07)$. Therefor, not continuous test to know the higher both of groups. Proportion of distractors three equals with proportion of distractors four, the result is anava test Fcount $(2,03)$ lower than Ftable $(3,07)$. Therefor, not continuous test to know the higher both of groups. 
Proportion of distractors two equals with proportion of distractors four, the result is anava test Fcount $(2,03)$ lower than Ftable $(3,07)$. Therefor, not continuous test to know the higher both of groups.

The conclusion is no differences between proportion of distractors two, proportion of distractors three, and proportions of distractor four. The research is novelty the proportion of distractors numbers in economic items grade 11 base on Bloom level of knowledge from C2, C3, C4, C5, dan C6.

Recommendation for teacher, teacher able to use the economic items questions by distractors two, distractors three, and distractors four and teacher need to pay attention the students understanding of economic subject and students are accustomed to understand the kinds of economic questionts items base on current standards for senior high school level. Recommendation for principle, principal do supervision in schools to increase of teacher competence. Recommendation for head of education office, the education office of Bekasi city held training to improve the quality of teachers in teaching competence and write manuscript of economics. Recommendation for other reasearcs, be expected able to related review of anothers factors such as score technic of teacher competence and others even related to the factor of students' ability to analysis.

\section{REFFERENCES}

Bachtiar, M.A., 2015. The effect of Khazanah program in trans7 on improving religious understanding of the community RT 02 RW 05 Berbek Village Waru subdistrict. Suarabaya: The Sunan Ampel Institute of Islamic Religion Surabaya.

Bhakti, Y.B., 2015. Influence of the number of alternative answers and scans techniques on test reliability. Formative Journal, 5(1): 1-13.

Kurzawa, D.D., 2011. Examination of the quality of multiple-choice. Canadian Journal for the Scholarship of Teaching and Learning, volume 2, issue 2, page number 10 .

Marie, T.J.W., 2009. An assessment of functioning and non-functioning distractors. BMC Medical Education: volume 9, issue 40, page number:1-8. Doi:10.1186/1472-6920-9-40.

Mkrtchyan, A., 2011. Distractor quality analyze in multiple choice. 3rd International Conference on Education and New Learning Technologies. Barcelona: State Engineering University of Armenia. pp: 1624-1631.

Musmuliadi, "Hubungan Model Penskoran Terhadap Estimasi Skor Sesungguhnya," Jurnal Penelitian dan Evaluasi Pendidikan, volume 13, issue 2, 2009. 13: 248 .

Norani, N.G., 2012. Implementation of learning methods quiz team variable can improve motivation and economic learning outcomes in students of class VIIIC SMP muhammadiyah 2 Surakarta academic year 2011/2012. Urakarta: Muhammadiyah University of Surakarta.

Rashmi, V., A. S., 2008. Multiple choice questions: A literature review on the optimal number of options. National Medical Journal of India, VOL. 21, Issue. 3, page number 132.

Sanju, G., R. S., 2014. Item and test analysis to identify quality multiple choice questions (MCQs) from an assessment of medical students of Ahmedabad, 
Gujarat. Indian Journal of Community Medicine: volume 39, issue 1, page number: 17-20. Doi: 10.4103/0970-0218.126347

Naga, D.S., 2012. Theory of scores on mental measurements. Jakarta: PT: Nagarani Cita Rasa.

Musmuliadi, 2009. Evaluation of learning. Jakarta: Youth.

Soleh, A.N., 2009. Building professional teacher. 3rd Edn., Jakarta: Elsals.

Sudjana, 2009. Statistical method. Bandung: Tarsito.

Suprananto, K., 2012. Measurement and assessment of education. Yogyakarta: Graha Ilmu.

Yamin, M., 2009. Teacher professionalization and KTSP implementation (2nd Edn). Jakarta: Gaung Persada Press. 